\title{
Quantification of road mortality for amphibians and reptiles in Hoces del Alto Ebro y Rudrón Natural Park in 2005
}

\author{
Fernando Martínez-Freiría*, José C. Brito \\ CIBIO, Centro de Investigação em Biodiversidade e Recursos Genéticos, Instituto de Ciências Agrárias de Vairão, Vairão, Portugal. \\ ${ }^{*}$ Correspondence: CIBIO, Centro de Investigação em Biodiversidade e Recursos Genéticos, Instituto de Ciências Agrárias de Vairão, \\ R. Padre Armando Quintas, 4485-661 Vairão, Portugal. Phone: +351 252660400, Fax: +351 252661780, E-mail: fmartinez-freiria@cibio.up.pt
}

Received: 3 August 2011; received in revised form: 5 January 2012; accepted: 12 January 2012.

Roads are one the most important human agents of transformation, producing direct non natural, negative effects in wildlife. This work quantified road mortality on amphibian and reptile species in the Hoces del Alto Ebro y Rudrón Natural Park (north of Spain). In 2005, two types of roads (seven secondary and one main road) were sampled by car in order to detect road-killed specimens. Geographical Information Systems (GIS) and G-tests were used for analysing data, and mortality indexes (MI, number of specimens / $100 \mathrm{~km}$ sampled) were used as descriptors of the mortality risk on wild species. A total of 291 specimens was recorded, 115 amphibians belonging to four species and 176 reptiles belonging to 13 species. Bufo bufo represented more than $88 \%$ of the amphibians with MI peaks in spring and autumn. Natrix maura, Vipera aspis and V. latastei were the most frequently found road-killed reptiles (54.5\%), presenting the two viper species MI peaks in spring. The number of road-kills was significantly higher in secondary roads than in the main one and also significantly high in well-preserved habitats. Three sections of high mortality were identified, all located in secondary roads that go through the Natural Park, enhancing the importance of habitat fragmentation as a major threat in biodiversity conservation. Management actions to reduce and/or eliminate the intensity of road mortality should be addressed in the Natural Park's management plan and detailed studies should be performed to evaluate the effectiveness of installing traffic signs, road barriers and/or under-road passages.

Key words: amphibians; GIS; Natural Park; northern Spain; reptiles; road-kills.

Cuantificación de la mortalidad de anfibios y reptiles en las carreteras del Parque Natural de las Hoces del Alto Ebro y Rudrón en 2005. Las carreteras son uno de los agentes antrópicos de transformación ambiental más importantes, produciendo efectos negativos no naturales en fauna silvestre. En este trabajo cuantificamos la mortalidad en las carreteras de las especies de anfibios y reptiles presentes en el Parque Natural de las Hoces del Alto Ebro y Rudrón (norte de España). En 2005, se muestrearon en coche dos tipos de carreteras (siete secundarias y una principal) para detectar especímenes atropellados. Usamos Sistemas de Información Geográfica (GIS) y test G para analizar los datos, empleando índices de mortalidad (MI, número de individuos atropellados / 100 km muestreados) como descriptores del riesgo de mortalidad para las especies silvestres. Se registraron un total de 291 especímenes atropellados, 115 anfibios pertenecientes a cuatro especies y 176 reptiles pertenecientes a 13 especies. Bufo bufo representó más del 88\% de los anfibios atropellados, con picos de mortalidad en primavera y otoño. Natrix maura, Vipera aspis y V. latastei fueron los reptiles atropellados con mayor frecuencia (54.5\%), presentando las dos especies de víboras picos de mortalidad en primavera. El número de atropellos fue significativamente más alto en las carreteras secundarias que en la principal, así como en los hábitats mejor conservados. Se identificaron tres tramos con una alta mortalidad, todos ellos localizados en carreteras secundarias que discurren por el Parque Natural, lo que resalta la importancia de la fragmentación del hábitat como gran amenaza en la conservación de la biodiversidad. El plan de manejo del Parque Natural debería incluir acciones para reducir y/o eliminar los atropellos, al tiempo que se deberían realizar estudios detallados que evalúen la efectividad de la instalación de señales de tráfico, barreras y/o pasos subterráneos en las carreteras.

Key words: anfibios; atropellos; GIS; norte de España; Parque Natural; reptiles. 
Landscape fragmentation is a major threat to the biodiversity conservation (SAUNDERS et al., 1991) and roads are one of the most important human agents of transformation (FORMAN et al., 2003). Roads produce direct non natural, negative effects on wildlife, such as increase of mortality due to collision with vehicles and also modification of animal behaviour (for revisions see TrombulaK \& Frissell, 2000; FAHRIG \& RYTWINSKY, 2009). As consequence, roads act as barriers to animal movement and reduce population connectivity, diminishing gene flow and limiting population dynamics, thus promoting inbreeding and loss of genetic diversity (FERRERAS, 2001; MARSH et al., 2005; Row et al., 2007).

Road-killing is one of the most important sources of unnatural mortality which have significant effects on populations of threatened and endangered species, including mammals, birds, reptiles, amphibians and invertebrates (TrombulaK \& Frissell, 2000; FAHrig \& RYTWINSKY, 2009). Among vertebrates, amphibians and reptiles present physiological, ecologi$\mathrm{cal}$ and behavioural traits that make them very vulnerable to roads (ANDREWs et al., 2008). They move slowly, have high dependency on particular habitats and exhibit seasonal movement patterns during which they are very vulnerable to road traffic. Thus, they are frequently found road-killed and many studies have quantified and evaluated the potential impact of road mortality in populations of both groups (e.g. BONNET et al., 1999; Hels \& BUCHWALD, 2001; Brito \& Álvares, 2004; Glista et al., 2007; Row et al., 2007).

The aims of this study are to quantify road mortality of amphibians and reptiles and identify road sections with higher mortality in the protected Hoces del Alto Ebro y Rudrón Natural Park (Northern Spain). Protected areas should preserve better communities of amphibians and reptiles (e.g. in terms of densities) than unprotected areas, since they are keeping high quality habitats. However, protected areas attract many vehicles in determinate seasons (e.g. tourism) and could present higher intensities of road mortality than unprotected areas. The present study is expected to contribute to the Natural Park's management plan by reducing the intensity of road mortality on amphibians and reptiles.

\section{MATERIALS AND METHOdS}

\section{Study area}

The study area is located in the high course of the Ebro river in northern Spain (latitude: 42o 37.7' - 42o 58.7’ N; longitude: 3o 37.3' $\left.3^{\circ} 58.5^{\prime} \mathrm{W}\right)$. It partially includes the recently protected Hoces del Alto Ebro y Rudrón Natural Park (JCYL, 2008), in north-western Burgos province, and the adjacent Valderredible valley, in south-eastern Santander province. It is a transition among Eurosiberian and Mediterranean regions (RIVAS-MARTíNEZ, 1987) and its landscape mainly consists of calcareous plateaus excavated by the Ebro river and its tributary, the Rudrón river, forming canyons and steep valleys. Climate is subhumid Mediterranean with Central European tendency (FonT Tullot, 1983).

\section{Amphibian and reptile species}

The study area has a relative high diversity of herpetofauna, with 13 and 16 species of amphibians and reptiles, respectively 
(Pleguezuelos et al., 2002). Moreover, given its condition of transition among bioclimatic regions, several species are at the border of their distributional range and/or in contact with species of the same genus (Sillero et al., 2009). The latter is the case of the Iberian vipers: the study area is the only known contact zone among the three species (Vipera aspis, V. latastei and V. seoanei), where $V$. aspis and $V$. latastei meet in sympatry and hybridize (for more details see MARTínEZFreIRía et al., 2008, 2009, 2010), enhancing the importance of this area in biogeographical and ecological studies.

\section{Road sampling}

A total of $82.11 \mathrm{~km}$ of roads was equally sampled by car with an average monthly frequency of 5.12 (range $=3-6$ ) samplings. Road sampling was performed from March to October of 2005 at a driving speed lower than $40 \mathrm{~km} / \mathrm{h}$. Two types of roads were sam- pled: one main road with $24.16 \mathrm{~km}$ of length and with high level of traffic circulation, and seven secondary roads with $57.84 \mathrm{~km}$ of length in total and with low level of traffic circulation (Table 1, Fig. 1).

Road-kills were identified to specific level using keys based on morphology (e.g. SALVADOR, 1998) and genetic markers (only for vipers, see MarTínez-Freiría et al., 2009), and their locations were recorded with a GPS (European Datum 1950).

\section{Road-kill data analyses}

Road-kill data were introduced in a georreferenced database and represented in ArcMap 9.3 GIS software (ESRI, Redlands, California, USA). GIS was used for two purposes: i) to extract habitat types for each road-kill by intersecting the road-kill location with Corine Land Cover 2006 raster data version 15 at a resolution of $100 \mathrm{~m}^{2}$ (EEA, 2011), and ii) to visualize and detect road sections of high mortality by

Table 1: Road length $(\mathrm{km})$, number $(\mathrm{N})$ and percentage (\%) of road-kills, and mortality index (MI) by roads sampled and in road sections with high mortality.

\begin{tabular}{ccccc}
\hline \hline & Road & Length $(\mathrm{km})$ & N (\%) & MI \\
\hline Main roads & N-623 & 24.16 & $35(12.03)$ & 144.87 \\
Secondary roads & & & \\
& BU-3345 & 16.40 & $98(33.68)$ & 597.56 \\
& BU-3342 & 9.46 & $71(24.40)$ & 750.53 \\
& BU-3465 & 7.00 & $5(1.72)$ & 71.43 \\
& CA-757 & 5.50 & $1(0.34)$ & 18.18 \\
& CA-274 & 3.82 & $6(2.06)$ & 157.07 \\
& CA-275 & 6.51 & $65(22.34)$ & 153.61 \\
& BU-613 & 9.26 & $256(87.97)$ & 401.94 \\
& Total & 57.95 & $65(22.34)$ & 1.76 \\
High mortality & & & $71(24.40)$ & 1050.82 \\
road sections & Section 1 & 4.36 & $65(22.34)$ & 701.94 \\
& Section 2 & 6.72 & $201(69.07)$ & 987.72 \\
\hline
\end{tabular}


measuring the degree of clustering of road-kill data using the Average Nearest Neighbor (ANN), Getis-Ord General G (GOG G) and Kernel density functions from ArcToolbox (ESRI, Redlands, California, USA).

G-tests were used to compare road-kill data by groups (i.e. amphibians and reptiles), subgroups (i.e. anurans, urodeles, lizards and snakes), species, months (from March to October), road types (i.e. main or secondary), roads (eight roads, see Table 1) and habitat types (eight classes including urban areas, bare areas, cultivated areas, grasslands, bushy areas, evergreen and deciduous forests, and river beds). Contingency tables, using G-test statistics, were also performed to test the relationship among groups, sub-groups and species with months, road types, roads and habitats. Statistical procedures were developed on R-software (R Development Core Team, 2010).
Mortality indexes (MI, number of specimens $/ 100 \mathrm{~km}$ of sampled road) were used as descriptors of the mortality risk by month, road type and road.

\section{RESULTS}

A total of 291 specimens were recorded (115 amphibians and 176 reptiles) from four amphibian and 13 reptiles species (Table 2). Hybrids between $V$. aspis and $V$. latastei were also found road-killed.

G-tests resulted in significant differences for all the variables when analysed separately but only for some pairs of variables when their relationship was analysed (Table 3 ).

Reptiles were more commonly road-killed than amphibians, being anurans and snakes the most frequently road-killed sub-groups (Table 2). Among the most frequently road-killed spe-
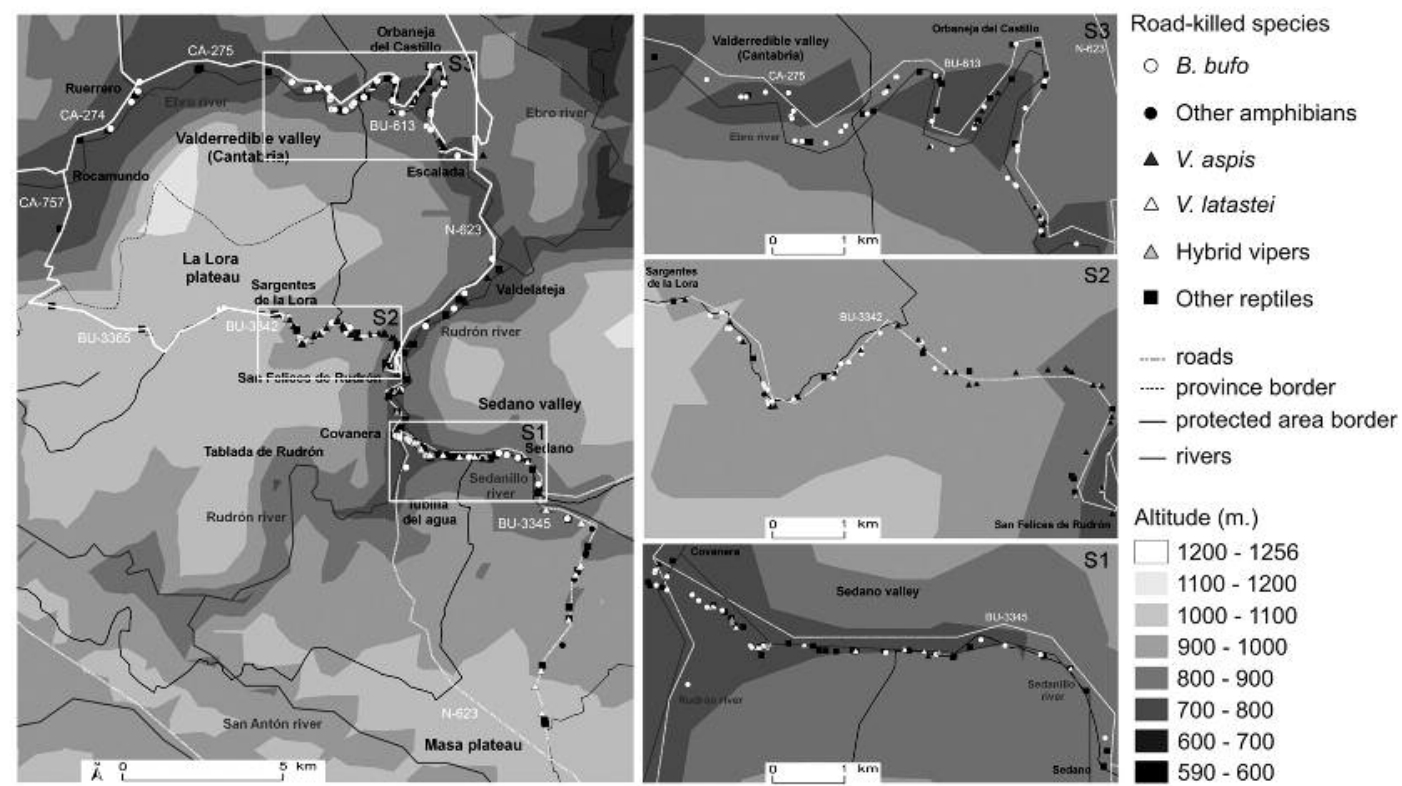

Figure 1: Sampled roads with the distribution of road-killed species (left). Maps on the right side depict particular road sections where high mortality was detected (S1: section 1, S2: section 2, S3: section 3). 
Table 2: Number of road-kills $(\mathrm{N})$, percentage of the total (\% total), percentage within each group (\% group) and mortality index (MI) by species and group.

\begin{tabular}{|c|c|c|c|c|}
\hline Taxa & $\mathbf{N}$ & $\%$ total & $\%$ group & MI \\
\hline Salamandra salamandra & 11 & 3.78 & 8.80 & 13.40 \\
\hline Triturus marmoratus & 1 & 0.34 & 0.80 & 1.22 \\
\hline Bufo bufo & 101 & 34.71 & 80.80 & 123.01 \\
\hline Pelophylax perezi & 2 & 0.69 & 1.60 & 2.44 \\
\hline Total Urodela & 12 & 4.12 & 9.60 & 14.62 \\
\hline Total Anura & 103 & 35.40 & 82.40 & 125.45 \\
\hline Total Amphibia & 115 & 39.52 & 100.00 & 140.07 \\
\hline Anguis fragilis & 11 & 3.78 & 6.25 & 13.40 \\
\hline Chalcides striatus & 4 & 1.37 & 2.27 & 4.87 \\
\hline Lacerta bilineata & 7 & 2.41 & 3.98 & 8.53 \\
\hline Lacerta schreiberi & 2 & 0.69 & 1.14 & 2.44 \\
\hline Timon lepidus & 8 & 2.75 & 4.55 & 9.74 \\
\hline Podarcis hispanica & 2 & 0.69 & 1.14 & 2.44 \\
\hline Coronella austriaca & 8 & 2.75 & 4.55 & 9.74 \\
\hline Coronella girondica & 10 & 3.44 & 5.68 & 12.18 \\
\hline Natrix maura & 25 & 8.59 & 14.20 & 30.45 \\
\hline Natrix natrix & 8 & 2.75 & 4.55 & 9.74 \\
\hline Vipera aspis & 46 & 15.81 & 26.14 & 56.02 \\
\hline Vipera latastei & 25 & 8.59 & 14.20 & 30.45 \\
\hline Vipera seoanei & 2 & 0.69 & 1.14 & 2.44 \\
\hline Hybrid vipers & 18 & 6.19 & 10.23 & 21.92 \\
\hline Total Sauria & 34 & 11.68 & 19.32 & 41.41 \\
\hline Total Colubridae & 51 & 17.53 & 28.98 & 62.11 \\
\hline Total Viperidae & 91 & 31.27 & 51.70 & 110.83 \\
\hline Total Ophidia & 142 & 48.80 & 80.68 & 172.94 \\
\hline Total Reptiles & 176 & 60.48 & 100.00 & 214.35 \\
\hline
\end{tabular}

cies one amphibian, Bufo bufo, and three snakes, Natrix maura, $V$. aspis and $V$. latastei, accounted for more than $67 \%$ of all road-killed specimens; this value is even higher $(73 \%)$ if hybrid vipers are added (Table 2, Fig. 1).

The number of road-killed animals was significantly different among months (Table 3), being April the month with the largest number of road-killed animals ( $\mathrm{N}=86 ; 29.6 \%$ ). Moreover, significant differences in the frequency of road-killed specimens were found when analysing the relationships between months and groups, sub-groups or species
(Table 3). The visualization of Fig. 2 allows the detection of monthly MI peaks in spring for B. bufo, $V$. aspis, $V$. latastei and for hybrid vipers, as well as for $B$. bufo and $V$. aspis in late summer and autumn.

The number of road-killed specimens was significantly higher in secondary roads than in the main road (Tables 1, 3). Significantly different frequencies were found among the studied roads when considering all the roadkills together and also when comparing by groups, sub-groups and species (Tables 1, 3). Three secondary roads mostly running 
Table 3: G-test of goodness of fit for road-kill data when testing for differences as a function of each variable or the relationship between two variables.

\begin{tabular}{cccc}
\hline \hline Variables & d.f. & G & $P$ \\
\hline Group & 1 & 12.882 & $<0.001$ \\
Sub-group & 3 & 166.589 & $<0.001$ \\
Species & 17 & 385.732 & $<0.001$ \\
Month & 7 & 111.318 & $<0.001$ \\
Road type & 1 & 193.555 & $<0.001$ \\
Road & 7 & 105.508 & $<0.001$ \\
Habitat & 7 & 297.474 & $<0.001$ \\
Group x Month & 7 & 75.578 & $<0.001$ \\
Group x Road type & 1 & 0.846 & 0.358 \\
Group x Road & 7 & 21.974 & 0.003 \\
Group x Habitat & 7 & 29.532 & $<0.001$ \\
Sub-group x Month & 21 & 92.012 & $<0.001$ \\
Sub-group x Road type & 3 & 3.498 & 0.321 \\
Sub-group x Road & 21 & 71.596 & $<0.001$ \\
Sub-group x Habitat & 21 & 42.586 & 0.004 \\
Species x Month & 119 & 198.525 & $<0.001$ \\
Species x Road type & 17 & 24.366 & 0.110 \\
Species x Road & 119 & 288.040 & $<0.001$ \\
Species x Habitat & 119 & 168.129 & 0.002 \\
\hline
\end{tabular}

within the protected area presented more than $80 \%$ of all road-killed specimens (Table 1, Fig. 1).

GIS cluster analyses resulted in a high degree of clustering for all road-kill data $($ ANN ratio $=0.22 ; Z=-25.70 ; P<0.001)$, mainly when roads were used as factors (GOG G $=0 ; Z=4.36 ; P=0.01$ ). Kernel density function allowed the identification of three sections within the three secondary roads with high mortality, having the $69.1 \%$ of all road-kills and the highest values of $\mathrm{MI}$ (Table 1, Fig. 1): 1) a section of BU-3345 presented $56 \%$ and $55.6 \%$ of all road-killed $V$. latastei and hybrid vipers, respectively; 2) a section of road BU-3342 presented $24.8 \%, 58.7 \%$ and $27.8 \%$ of all road-killed $B$. bufo, $V$. aspis and hybrid vipers, respectively; and 3) a section of road BU-613 presented $37.6 \%$ and $19.6 \%$ of all road-killed B. bufo and $V$. aspis, respectively.

The number of road-killed animals was significantly different among the different types of habitats (Table 3), being more frequent in bushy $(\mathrm{N}=117 ; 40.2 \%)$ and cultivated areas $(\mathrm{N}=64 ; 21.9 \%)$, and in river beds $(\mathrm{N}=48 ; 16.5 \%)$. Also, significant differences were found for the number of roadkilled groups, sub-groups and species by habitat (Table 3). Bufo bufo was found most frequently road-killed in bushy areas $(\mathrm{N}=37$; $36.6 \%), N$. maura in cultivated $(\mathrm{N}=7$; $28.0 \%)$ and bushy areas $(\mathrm{N}=8 ; 32.0 \%)$, and in river beds $(\mathrm{N}=7 ; 28.0 \%), V$. aspis in bushy areas $(\mathrm{N}=17 ; 36.9 \%)$, evergreen $(\mathrm{N}=11$; $23.9 \%)$ and deciduous forests $(\mathrm{N}=8 ; 17.4 \%)$, $V$. latastei in cultivated $(\mathrm{N}=14 ; 56.0 \%)$ and bushy areas $(\mathrm{N}=10 ; 40.0 \%)$ and hybrid vipers in bushy areas $(\mathrm{N}=11 ; 61.1 \%)$.

\section{DisCUSSION}

The present single-year estimation of road mortality is the first systematic evaluation of road-killing on amphibians and reptiles in the Hoces del alto Ebro y Rudrón Natural Park. Opportunistic road sampling series conducted in the area during 2006 and 2007 reported similar results regarding most frequent roadkilling species and sections of roads with high mortality (authors' unpublished data).

Road-traffic circulation during 2005 induced high mortality over the amphibians and reptiles in the protected area, especially in B. bufo, N. maura, $V$. aspis, $V$. latastei and hybrid vipers. Anurans and snakes have been reported to be the groups with higher vulnerability to road mortality within amphibians and 


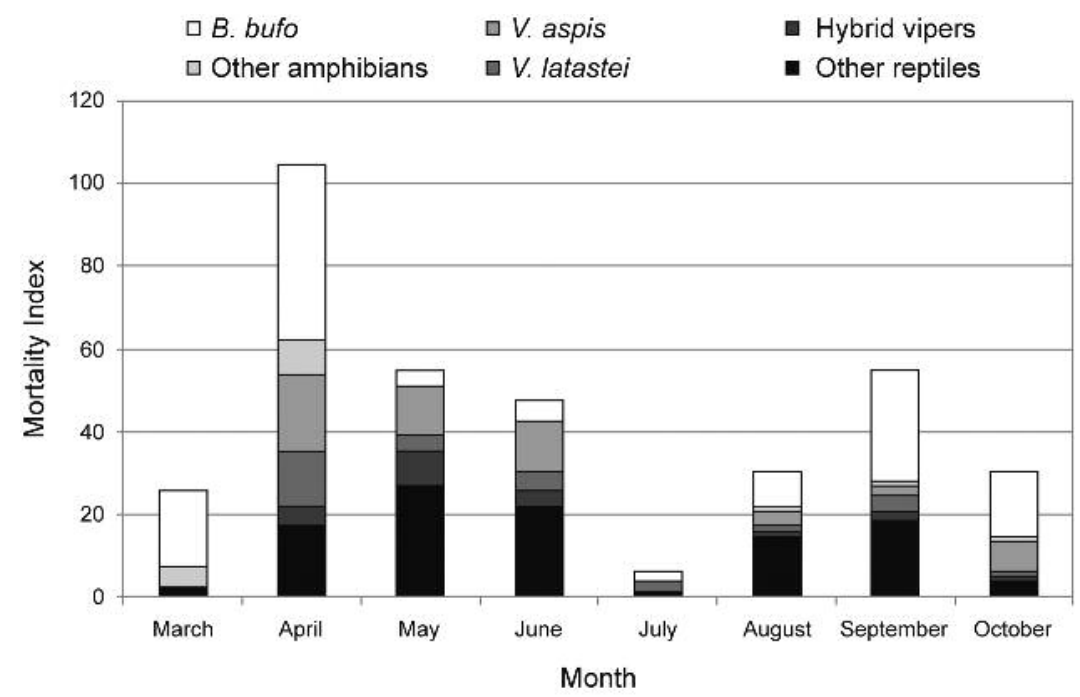

Figure 2: Monthly variation of the mortality index for the most frequently roadkilled species and groups.

reptiles, respectively (TROMBULAK \& FrISSELL, 2000). The observed monthly pattern of road mortality for these groups seems to be related to seasonal movements from a particular habitat to another (ANDREWs et al., 2008). Bufo bufo had a bimodal road mortality pattern probably related to the annual migration to reproduction sites (Hels \& BUCHWALD, 2001). Vipera aspis, V. latastei and hybrid vipers exhibited a unimodal road mortality pattern, with a mortality peak in spring, probably related to dispersal activities after hibernation and mating season (BONNET et al., 1999; BRITO \& ÁlVARES, 2004; Row et al., 2007; MARTÍnEZFREIRÍA et al., 2010). Vipers were the most road-killed snakes and reptiles. The high viper densities in the study area (MARTÍNEZ-FrEIRÍA et al., 2010), the use of roads for thermoregulation and the slow locomotion are probably the factors that explain this pattern (BONNET et al., 1999; BRITO \& ÁlvarEs, 2004).

Road-kills were not randomly spatiallydistributed throughout the roads of the study area. In fact, this study identified road-kill aggregations mainly in three sections of secondary roads in the protected area, which represented about the $25 \%$ of all sampled roads. Landscape variables, including topography and habitat composition, would be expected to play an important role in determining road-kill aggregations but also road variables such as intensity of traffic circulation (Ferreras, 2001; Clevenger et al., 2003). In our study, secondary roads presented lower intensity of traffic circulation than main roads but presented higher levels of road-kills. Due to low permanence of amphibian and reptile carcasses on the roads (SANTOS et al., 2011), road-sampling effort (i.e. monthly road sampling frequency) performed in the current study could be obscuring the detection of more accurate patterns of road mortality in main roads. However, among the secondary roads, with similar intensity of traffic circulation, those going through the protected area presented higher number of road-kills than roads located outside. This suggests that landscape could be playing an important role in the observed pattern of road mortality in secondary roads. 
The topography of the protected area is quite different from the surroundings (steep valleys and canyons vs. flat areas) and road-kills were more common in well-preserved habitats (e.g. road-kills in bushy areas and river beds represented about $56 \%$ of all road-kills) than in the other habitats. The only exception appears in cultivated areas, which also presented high road-kill numbers $(21.95 \%$ of all road-kills); however, in the protected area, cultivated lands have been abandoned since the 1970s and currently present herbaceous and bushy vegetation, favouring high densities of amphibians and reptiles (e.g. MARTINEZ-FrEIRÍA et al., 2010). Therefore, the three sections of secondary roads with high mortality are probably acting as major agents of habitat fragmentation and barriers to wildlife movements, since they go along of the canyons, close to rivers, and divide patches of well-preserved habitats.

Road-sampling effort should be increased in future studies to obtain more accurate patterns of road mortality (SANTOS et al., 2011), and also management strategies to reduce the intensity of road mortality should be addressed in the Natural Park's management plan (e.g. Hels \& Buchwald, 2001; Brito \& Álvares, 2004; Glista et al., 2007; Row et al., 2007; WOLTZ et al., 2008). These strategies should consider: i) installation of signals and construction of road barriers and under-road passages to prevent road mortality; ii) translocation of living animals and removal of carcasses found on roads to prevent further mortality; iii) studies quantifying population structure and connectivity using molecular tools to identify potential roadbarriers to gene flow; and iv) local environmental education campaigns promoted by the Natural Park administration.

\section{Acknowledgement}

Authors want to thank to Asociación sociocultural Hoces del Alto Ebro y Rudrón (Burgos, Spain), friends who helped in the interminable hours of road-sampling and P. Tarroso for his support in the analyses. FMF and JCB are supported by FCT (SFRH/BPD/69857/2010 and Programme Ciência 2007, respectively).

\section{REFERENCES}

Andrews, K.M.; GibbOns, J.W. \& JOCHIMSEN D.M. (2008). Ecological effects of roads on amphibians and reptiles: a literature review, In J.C. Mitchell, R.E. Jung Brown \& B. Bartholomew (eds.) Urban Herpetology. Series: Herpetological Conservation, vol. 3. Society for the Study of Amphibians and Reptiles, Salt Lake City, Utah, USA, pp. 121-143.

Bonnet, X.; Naulleau, G. \& Shine, R. (1999). The dangers of leaving home: dispersal and mortality in snakes. Biological Conservation 89: 39-50.

Brito, J.C. \& Álvares, F. (2004). Patterns of road mortality in $V$. latastei and $V$. seoanei from northern Portugal. AmphibiaReptilia 25: 459-465.

Clevenger, A.P.; Chruszcz, B. \& Gunson, K. (2003). Spatial patterns and factors influencing small vertebrate fauna road-kill aggregations. Biological Conservation 109: 15-26.

EEA (2011). Corine Land Cover 2006 raster data - version 15 (08/2011). European Environment Agency, Copenhagen, Denmark. Avalaible at http://www.eea. europa.eu/data-and-maps/data/corineland-cover-2006-raster-1. Retrieved on 12/12/2011. 
FAHRIG, L. \& RYTWINSKY, T. (2009). Effects of roads on animal abundance: an empirical review and synthesis. Ecology and Society 14: 21.

FERRERAS, P. (2001). Landscape structure and asymmetrical inter-patch connectivity in a metapopulation of the endangered Iberian lynx. Biological Conservation 100: 125-136.

Font Tullot, I. (1983). Climatología de España y Portugal. Instituto Nacional de Meteorología, Madrid, Spain.

Forman, R.T.T.; SPERling, D.; BisSONETTE, J.A.; Clevenger, A.P.; Cutshall, C.D.; Dale, V.H.; Fahrig, L.; France, R.; Goldman, C.R.; Heanue, K.; Jones, J.A.; Swanson, F.J.; Turrentine, T. \& WinTER, T.C. (2003). Road Ecology: Science and Solutions. Island Press, Washington, DC, USA.

Glista, D.J.; DeVault, T.L. \& DeWoody, J.A. (2007). Vertebrate road mortality predominantly impacts amphibians. Herpetological Conservation and Biology 3: 77-87.

Hels, T. \& Buchwald, E. (2001). The effect of road kills on amphibian populations. Biological Conservation 99: 331-340.

JCYL (2008). Red de Espacios Naturales. Junta de Castilla y León, Valladolid, Spain. Available at http://www.jcyl.es/web/jcyl/ MedioAmbiente/es/Plantilla100/1131977 537178/_/__. Retrieved on 03/12/2008. Marsh, D.M.; Milam, G.S.; Gorham, N.P. \& BeCKMAN, N.G. (2005). Forest roads as partial barriers to terrestrial salamander movement. Conservation Biology 19: 2004-2008.

MarTínez-Freiría, F.; Sillero, N.; Lizana, M. \& BRITO, J.C. (2008). GIS-based niche models identify environmental correlates sustaining a contact zone between three species of European vipers. Diversity and Distributions 14: 452-461.

Martínez-Freiría, F.; Santos, X.; Pleguezuelos, J.M.; Lizana, M. \& BRITO, J.C. (2009). Geographical patterns of morphological variation and environmental correlates in contact zones: a multi-scale approach using two Mediterranean vipers (Serpentes). Journal of Zoological Systematics and Evolutionary Research 47: 357-367.

Martínez-Freiría, F.; LizAna, M.; Amaral, J.P. \& BRito, J.C. (2010). Spatial and temporal segregation allows coexistence in a hybrid zone among two Mediterranean vipers (Vipera aspis and V. latastei). Amphibia-Reptilia 31: 195-212.

Pleguezuelos, J.M.; Márquez, R. \& LizAna, M. (2002). Atlas y Libro Rojo de los Anfibios y Reptiles de España. Dirección General de Conservación de la Naturaleza - Asociación Herpetológica Española, Madrid, Spain.

R Development Core Team (2010). $R$ : $A$ Language and Environment for Statistical Computing. R Foundation for Statistical Computing, Vienna, Austria. Available at http://www.r-project.org/. Retrieved on 12/12/2011.

Rivas-MarTíneZ, S. (1987). Memoria del Mapa de Series de Vegetación de España. Ministerio de Agricultura, Pesca y Alimentación, ICONA, Madrid, Spain.

Row, J.R.; Blouin-Demers, G. \& Weatherhead, P.J. (2007). Demographic effects of road mortality in black ratsnakes (Elaphe obsoleta). Biological Conservation 137: 117-124. 
Salvador, A. (1998). Reptiles. Series: Fauna Ibérica, vol. 10 (M.A. Ramos, coord.). Museo Nacional de Ciencias Naturales, CSIC, Madrid, Spain.

Santos, S.M.; Carvalho, F. \& Mira, A. (2011). How long do the dead survive on the road? Carcass persistence probability and implications for road-kill monitoring surveys. PLoS ONE 6: e25383.

Saunders, D.A.; Hobbs, R.J. \& Margules, C.R. (1991). Biological consequences of ecosystem fragmentation: a review. Conservation Biology 5: 18-32.
Sillero, N.; Brito, J.C.; Skidmore, A.K. \& ToXopeus, A.G. (2009). Biogeographical patterns derived from remote sensing variables: the amphibians and reptiles of the Iberian Peninsula. Amphibia-Reptilia 30: 185-206.

TrombulaK, S.C. \& Frissell, C.A. (2000). Review of ecological effects of roads on terrestrial and aquatic communities. Conservation Biology 14: 18-30.

Woltz, H.W.; GibBs, J.P. \& DuceY, P.K. (2008). Road crossing structures for amphibians and reptiles: Informing design through behavioral analysis. Biological Conservation 141: 2745-2750. 